squarely before the Baltimore meeting. Dr. Quimby's United States, even though he $i s$ member of the AmerICAN motion is to "change the Code of Ethics-Duties for the Sup- Menical A ssociation"?

port of Professional Character-by leaving out the words 'Surgical Instruments,' in second line, Clause 5, Article I."

To spare the precious time of the meeting and to "hedge" against the possibility of my not being able to be present when this question comes up, please allow me to give a few reasons why this change should certainly be made, and the mechanical device or "surgical instrument" be forever divorced from the low company of "a secret nostrum."

As a preliminary let me observe, with all due respect for our professional grandmothers who framed the Code and Constitution of the American Medical Association, that the horizon of their vision of the possibilities of invention must have been rather narrow. The conditions were so different then from what they are now. Then, with few inventions made by medical men, and few patents issued to anybody, there was no need apparent to protect any physician in his right to be honored as the originator of anything. Now there is every need, and the Patent Office is the only reliable criterion by which to decide if a man has even made an original invention. To require that a man should prove his title and then deprive him of the only means of so doing reminds one of that old college song:

$$
\begin{aligned}
& \text { "Mother, may I go to swim?" } \\
& \text { "Yes, my darling daughter; } \\
& \text { Hang your clothes on a hickory limb, } \\
& \text { But don't go near the water." }
\end{aligned}
$$

The question is not whether it will pay for a physician to take out a patent on an invention. Judging by the fortyfive thousand or more patents already allowed in the United States, and only one in fifteen a financial success, it would probably not pay, and the applicant would have a "heap of bother" and considerable expense in return for the establishment of his own originality and a possible service he may do his fellow men.

Briefly stated, the arguments which seem to me sufficient to warrant this proposed change in the Code are:

1. That the intrusion of the words "surgical instruments" is uncalled for and without good excuse. It is out of harmony with the rest of the paragraph, for there is no fraud or secrecy to be avoided, as implied with regard to "secret nostrums." The latter are generally known to be cheats, while the former bear "upon their face" their evidence of worth and fitness.

2. The interdiction of "surgical instruments," and by im plication probably(?) mechanical devices, is wrong, because the Patent Office furnishes the only reliable proof that a claimant is entitled to credit.

3. The sacrifice in time, thought and expenditure required of a physician is really a damage to the medical profession, not to mention the deprivation to those who depend upon our aid, because many new things must be made, if at all cheaply, by dies and machinery, and manufacturers will demand protection for their own outlay. Especially is this the case with all hard rubber goods which have to be made in expensive molds.

4. The restriction imposed is unjust to the physician inventor, because he (co-equal with an outsider) ought to have the stimulus of credic and profit, if there is any, in order to make a success of his invention. The field is the world, and after all the great test of merit is extended use, and the sources of profit must be massed and under rightful control in order to secure such introduction to supply demand. The writer could illustrate this point by the failure of meritorious, mechanical, surgical inventions which have come short of recognition and use because of the lack of properly sanctioned pushing of their undoubted claims upon the attention of those who should employ them. Again he could illustrate a point taken (3) by stating that he has lately been requested to indorse a poor make of his stethoscope. with which it is proposed to undersell the market, and cal culated to bring discredit upon an instrument the utility of which, when properly made is unquestioned. And now when he is just finishing an improved stethoscope, made on similar but new lines and measurements, he is warned that he must secure the same by patent, or So-and-So-manufacturers-will cheapen the thing to capture the trade, regardless of his wishes to hold the instrument to an even grade of excellence. What shall be done under such circumstances? Shall the author take the advice given him by two ex-Presidents of the American Medical Association and get behind a surgical instrument company who will seek protection from the Government for him? or shall he be open-handed and boldly announce that his own rights in the matter are just the same as those of any citizen of the
The best way is to change the blamed paragraph and make it read as though a sane man had originally written it. Yours respectfully, Charles Denison, M.D.

\section{The Judicial Councill.}

Philadelphia, April 10, 1895.

To the Editor:-The Journal of the 6th inst. contains a criticism of the circular, relative to advertisements, recently sent to all members of the American Medical Association by the Philadelphia County Medical Society. In the criticism occurs a personal allusion which impels me to request the publication of this letter. The Journal sajs: "There are two direct mis-statements in the committee's report which we are sure they will be glad to have corrected; one is that the decision of the Judicial Council was not given to them or published. We notice that Dr. John B. Roberts has signed this document, and that he was also Secretary of the Judicial Council. If he failed to notify his associates on the committee of the action of the Council surely the JoURNAL is not to blame."

It is true that I was a delegate of the Philadelphia County Medical Society to the meeting of the American Medical Assocration at San Francisco, and therefore signed the report made by the delegation after its return to Philadelphia. It is also a fact that I was and am the Secretary of the Judicial Council of the Association.

The circumstance that I held the two positions and could have disclosed the decision of the Judicial Council to my associates of the delegation, seems to the Jounnal a sufficient reason for supposing that I would do so. Such a betrayal of official confidence would, in my opinion, make me unworthy to be a member of the Council.

As Secretary. I was directed to furnish the Board of Trustees with a copy of the decision in regard to the publication in the Joursal of advertisements of secret preparations. I did this immediately, on June 8,1894 . I was not at liberty to inform any one else, outside of the membership of the Council, not even those who brought the charges against the Trustees. I therefore have refrained from doing so.

You will remember that I declined to be present during the executive sessions of the Judicial Council at which the question was considered, because of $\mathrm{my}$ official connection with the Society bringing the charges. After the decision of the Council had been made, I returned to the room and resumed the duties of Secretary, which during my absences had been performed by Dr. X. C. Scott, and Dr. T. D. Crothers respectively acting as Secretary pro tempore. Yours truly, JoHN B. RoBerTs, M.D.

ANswer:-The decisions of the Judicial Council are not secret. The proceedings are secret, but not the decisions. The copy sent the Trustees was signed by Dr. Roberts.

\section{Mountain Air for Cities.}

Milton, Ky., April 15, 1895.

To the Editor:-The details of the plan which I suggested in the Journal of March 30, for supplying pure air to cities are as follows: Upon a sufficient foundation is a frame thirty feet high, within which is an elevator running to top of frame, for the purpose of raising the perpendicular sections of steel plate pipes, each of which is twenty feet long, and each one is larger than the one above it, to which it is securely bolted, and also of heavier plate. When the first two joints are securely joined at the top of frame they are elevated until another is added and so on until the first attains the desired height. Guys are attached and are so arranged as to maintain the pipe perpendicularly.

Electric lights could be attached to the top of the pipe, and being at an elevation of six hundred feet would be at least quite conspicuous.

The lower end of the pipe is attached to the cylinder of a pump which draws the air down through the pipe and forces it through the supply pipes to the desired apartments. These rooms should be practically air-tight except the ventilator at the lower, and the supply pipe at the upper part of the room. The air from an altitude of six hundred feet, being so much lighter than the impure air at the surface of the earth would force the latter out of the room, the temperature of which could be regulated by passing the supply pipes through either cold or hot media. A room thus furnished and covered with glass would be an ideal mountain resort. 